\title{
KAAWAKAN ULUN
}

\section{Oleh : Fauji Romansyah}

\author{
Dosen Pembimbing I Dindin Heryadi, S.Sn., M.Sn. Dosen Pembimbing II \\ Dra. Raja Alfirafindra,M.Hum. \\ Jurusan Seni Tari Fakultas Seni Pertunjukan Insitut Seni Indonesia Yogyakarta \\ Jl. Parangtritis km. 6,5 Sewon, Bantul, Yogyakarta \\ Email : fauji.romansyah@yahoo.com (085246187852)
}

\section{RINGKASAN}

"Kaawakan Ulun" merupakan sebuah judul karya koreografi pada tugas akhir yang penata tempuh pada semester genap tahun akademik 2015/2016. Koreografi Kaawakan Ulun menceritakan tentang pengalaman penata yang kembali dan menemukan kenyamanan dalam bergerak, menari serta kebudayaan penata dengan melihat tradisi dari daerah penata. Kata Kaawakan Ulun, berasal dari kata dasar Awak dan Ulun, kedua kata tersebut diambil dari bahasa daerah suku Banjar, salah satu suku yang ada di Kalimantan Selatan.

Koreografi Kaawakan Ulun, hadir dalam bentuk koreografi kelompok, yang menggambarkan atau menceritakan pengalaman penata yang tidak tahu akan tari tradisional dari daerah penata sendiri. Seiring berjalannya waktu, penata mulai merasa malu karena tidak mengetahui tari tradisional yang berasal dari Kalimantan Timur. Penata mulai mencari tahu dan mempelajari tari tradisional Kalimantan Timur, melalui teman-teman yang ada disekitarnya yang berasal dan memiliki kebudayaan yang sama dengan penata. Sehingga akhirnya penata sadar, bahwa tari tradisional sangatlah istimewa dan indah, sehingga munculah ide untuk menggarap unsur budaya tradisional dengan ketubuhan yang penata miliki, untuk dikolaborasikan hingga menjadi satu kesatuan yang harmonis dan indah.

Koreografi Kaawakan Ulun ini, penata masukan beberapa unsure budaya yang ada di Kalimantan Timur, yaitu unsur budaya Pedalaman atau Dayak dan unsur budaya Pesisir atau Melayu Kutai. Koreografi ini di dalamnya juga hadir permainan Flag Marching Band sebagai salah satu properti tari. Musik pengiring koreografi ini juga mengikuti kedua unsure budaya tersebut. Sumber suara pada musik pengiring ini tidak hanya bersumber dari alat musik tradisional dan musik digital yang diciptakan melalui program komputer saja, namun juga bersumber dari suara vokal seperti senandung, agar suasana khas dari Kalimantan Timur tambah terasa.

Kata kunci : Koreografi, Kalimantan Timur, Ketubuhan

\begin{abstract}
"KaawakanUlun" is the title of choreographic creation on the final project that artist btained on the second semester of the 2015/2016 academic years. This dance tells about flashback of choreographer's experiences that found comfort in moving. KaawakanUlun, derived from the base word Awak and Ulun, that words are taken from Banjar language, one of the ethnic in South Kalimantan. This dance presented in a form of choreography group. The dance describes the choreographer's experience who did know traditional dances from choreographer's own. Over time, the choreographer began to feel embarrassed because he did not know the traditional dances that originated from East Kalimantan. Furthermore, the choreographer began to seek out and learned
\end{abstract}


traditional dance of East Kalimantan from friends who comes from the same culture. Finally choreographer understood that traditional dance is very special and beautiful. So came idea to make creation with element that choreographer has. It was be collaborate and became a harmonious and beautiful dance.

Choreographer combined some elements of that exist in East Kalimantan. That ware outback area or Dayak culture and coastal or Malay culture. In this dance choreographer used Marching Band flags as one of the properties dance. The music followed both of the cultures. The musical accompaniment not only from musical instruments and digital music that created by using computer program but also from the sound like humming so the atmosphere like East Kalimantan tasted.

Keywords: dance, East Kalimantan, culture

\section{PENDAHULUAN}

Karya ini terinspirasi dari pengalaman pribadi penata yang merasa tidak memiliki kemampuan untuk menari tarian tradisional terutama tarian tradisional yang berasal dari daerah sendiri yaitu Kalimantan Timur.

Melalui pendidikan tari yang sedang dijalani sekarang ini membuat penata mulai mengenal tari tradisional. Hal ini membuat penata merasa malu karena tidak tahu budaya daerah asal, maka penata mulai mencari serta belajar tarian tradisional Kalimantan Timur.

Tari tradisional menurut sebagian orang terkesan monoton, membosankan dan kurang menarik. Perasaan tersebut juga sempat piñata rasakan sebelum penata memutuskan untuk masuk dan menuntut ilmu di Jurusan Tari Institut Seni Indonesia Yogyakarta. Saat mulai belajar di Institut Seni Indonesia Yogyakarta, barulah penata sadar bahwa budaya dan tradisi itu sangat indah, sangat mahal dan sangat elegan.

Sebagai mahasiswa baru di Jurusan Tari, sering kali pada awal masa perkuliahan para senior meminta para junior untuk menarikan tarian tradisional dari daerah masing-masing. Keadaan ini membuat piñata merasa khawatir karena bingung apa yang akan penata tunjukkan di depan para senior dan teman-teman semua, sedangkan pada saat tes masuk kuliah penata hanya menampilkan tari yang berasal dari daerah lain yaitu tari Indang dan saat itu penata hanya mempelajari tari tersebut melalui video yang penata download dari youtube. Walaupun demikian piñata tetap mencoba untuk menampilkan gerak tari tradisional Kalimantan Timur sebatas kemampuan yang penata miliki. Karena keberanian piñata untuk mencoba menarikan tari tradisional Kalimantan Timur ini, akhirnya penata mendapat beberapa perkataan yang kurang menyenangkan, sehingga membuat penata merasa malu.

Akhirnya dari pengalaman yang kurang menyenangkan ini piñata menyadari bahwa kemampuan tari yang penata miliki belum ada apaapanya dan masih sangat jauh dan sangat dangkal. Penata menyadari dan berkata dalam hati bahwa belum menjadi seorang penari seutuhnya, jika tidak bisa menari tarian daerah khususnya tari daerah Kalimantan Timur.

Rasa malu dan minder masih sering hadir kembali jika melihat temanteman lain dapat dengan bangga dan lenturnya menarikan tarian tradisional daerahnya masing-masing. Berawal dari rasa malu ini akhirnya

memicu penata untuk mencari tahu dan belajar tari tradisional daerah

Kalimantan Timur melalui teman-teman yang dekat dan satu daerah dengan penata. Lidwina Lirung yang menjadi sosok sahabat sekaligus 
kakak bagi penata sangat berperan penting terhadap kemajuan kemampuan penata dalam menari tardisional Dayak dan Melayu Kutai, Lidwina Lirung banyak memberi pelajaran dan pengetahuan kepada penata tidak hanya dalam tari namun pengetahuan-pengetahuan umum mengenai budaya Kalimantan Timur juga turut diberikan kepada penata, tidak jarang penata meminta bantuan kepada Lidwina Lirung dalam mengerjakan dan menyelesaikan tugastugas kampus terutama tugas-tugas yang membahas masalah budaya dari daerah asal. Keingintahuan piñata untuk mengenal dan belajar tari tradisional Kalimantan Timur ini membuat penata beberapa kali diberi kesempatan oleh Lidwina Lirung untuk terlibat dalam kegiatan atau tampil dengan menarikan tari tradisional Kalimantan Timur bersama teman-teman yang juga berasal dari Kalimantan Timur.

Pengalaman inilah yang membuat penata semakin tertarik untuk mengangkat penjelajahan diri dalam mencari serta mengembangkan gerak-gerak tradisional untuk dituangkan kedalam sebuah karya tari. Unsur gerak yang sesuai dengan ketubuhan penata sebelum mengenal tari tradisional juga dihadirkan dalam garapan ini sebagai perkenalan tentang penata yang tidak mengenal budaya ataupun tari tradisional daerah Kalimantan Timur. Gerak-gerak ini lebih akrab dan biasa penata tarikan sebelum penata belajar di Institut Seni Indonesia Yogyakarta, selain gerak tersebut gerak-gerak tari dari kedua unsur budaya yang terdapat di Kalimantan Timur yaitu Dayak dan Melayu Kutai juga penata gunakan dengan mengembangkan beberapa aspek seperti tempo, level, tenaga, ruang dan aksi. Aksen khas suku Dayak Kalimantan Timur berupa teriakan yang sering disebut nguhuk di dalam garapan tari ini juga dihadirkan dan dilakukan oleh para penari agar suasana Dayak makin terasa. Menurut Lidwina Lirung nguhuk biasanya sering dilakukan ketika sedang berburu di dalam hutan, orang-orang suku Dayak khususnya lakilaki biasanya akan berteriak untuk mencari tahu apakah ada orang lain di dalam hutan tersebut, jika di hutan tersebut ada orang lain maka orang tersebut akan menjawab teriakan tersebut dengan berteriak juga (Wawancara dengan Lidwina Lirung, seniman tari Kalimantan Timur, berusia 37 tahun, pada tanggal 21 Maret 2016, di kediaman Fauji Romansyah Jl Jogoripon Yogyakarta (diijinkan untuk dikutip).

Nguhuk juga sering dijumpai pada tari tradisional Dayak khususnya tari-tari yang dilakukan oleh laki-laki. Musik pengiring pada koreografi ini menggunakan musik digital yang dibuat melalui program aplikasi komputer dan ditambah suara dari alat-alat musik yang diselipkan dengan cara direkam. Alat musik tersebut berupa sape dan gambus serta dimasukan suara-suara yang membangun suasana. Sentuhan music Datun, Kancet Pepatay yang lebih berfokus pada suara sape, serta irama Tingkilan juga dihadirkan pada koreografi ini.

Kegiatan penata menjadi pelatih Colour Guard dan sempat tergabung dalam sebuah Marching Band sebagai Colour Guard menginspirasi pada sebuah bagian adegan dalam koreografi ini. Gerak yang menggunakan properti tongkat dan bendera ini turut hadir pada koreografi Kaawakan Ulun.

Tari merupakan kegiatan yang penata sukai sejak lama, namun selain tari penata juga memiliki hobi merancang dan membuat ostum. Kemampuan dan hobi ini dituangkan kedalam kostum yang digunakan pada koreografi ini.

Seperti yang telah dipaparkan di atas pada garapan ini terdapat dua unsur budaya radisional, begitu juga kostum yang dibuat. Kostum yang dikenakan pada koreografi ini menggunakan warna-warna yang memiliki arti dan simbol tertentu di Kalimantan Timur, seperti warna kuning yang memiliki makna keagungan dan warna hijau yang memiliki makna kesuburan, ketentraman dan keindahan. Makna warna ini juga biasa ditemukan pada pernak pernik manik khas Kalimantan Timur (http://www.kutaikartanegarakab.go.id/index.p hp/static/lambang_kabupaten/. Pemerintah Kabupaten Kutai Kartanegara. Lambang Kabupaten . 2013. Diunduh pada tanggal 16 
September 2015.) dan lambang Kabupaten Kutai Kartanegara4. Lidwina Lirung mengatakan warna hijau dan kuning merupakan warna khas yang terdapat di Kalimantan Timur, selain dua warna itu warna hitam, putih dan merah juga warna-warna yang khas di Kalimantan Timur (http://www.kidnesia.com/Kidnesia2014/Indon esiaku/Jalan-Jalan/Rahasia-Warna-Manik

Manik Dayak. Lita. Rahasia Warna ManikManik Dayak. Agustus 2015. Diunduh pada tanggal 16 September 2015) dan lambang Kabupaten Kutai Kartanegara (http://www.kidnesia.com/Kidnesia2014/Indon esiaku/Jalan-Jalan/Rahasia-Warna-Manik

Manik Dayak. Lita. Rahasia Warna ManikManik Dayak. Agustus 2015. Diunduh pada tanggal 16 September 2015). Lidwina Lirung mengatakan warna hijau dan kuning merupakan warna khas yang terdapat di Kalimantan Timur, selain dua warna itu warna hitam, putih dan merah juga warna-warna yang khas di Kalimantan Timur (Wawancara dengan Lidwina Lirung, seniman tari Kalimantan Timur, berusia 37 tahun, pada tanggal 12 Maret 2016, di rumah makan siap saji Mcdonald jalan Sudirman Yogyakarta (diijinkan untuk dikutip).

\section{PEMBAHASAN}

\section{A. Rangsang}

Rangsang bagi komposisi tari dapat berupa auditif, visual, gagasan, rabaan atau kinestetik (Jacqueline Smith, 1975. Dance Composition A Practical Guide for Teacher Terjemahan Ben Suharto. Yogyakarta: Ikalasti Yogyakarta. P. 20). Rangsang awal pada koreografi Kaawakan Ulun ini adalah rangsang gagasan atau ide, karena pada karya ini terdapat beberapa adegan atau alur serta gerak yang terinspirasi oleh pengalaman penata ketika menjalani proses penjelajahan diri dalam mencari tahu dan belajar tari tradisional Kalimantan Timur. Rangsang kinestetik juga menjadi rangsang pada koreografi ini. Gerak-gerak khas pedalaman suku Dayak dan gerak- gerak ataupun motif- motif tari khas pesisir Melayu Kutai, seperti motif ngancet, kepak enggang, samba, ayun anak, tahtim, dan ndayung, menjadi rangsang terciptanya gerak-gerak atau motif yang penata gunakan pada koreografi ini.

\section{B. Tema}

Tema dari koreografi Kaawakan Ulun ini adalah penjelajahan diri dalam mencari serta mengembangkan gerak-gerak tradisional. Melalui pengalaman yang pernah penata alami, serta proses pencarian dan proses belajar untuk mengetahui tari tradisional Kalimantan Timur, maka penjelajahan diri dalam mencari serta mengembangkan gerakgerak tradisional menjadi tema yang penata angkat ke dalam koreografi ini.

\section{Judul Tari}

Judul dalam sebuah karya khususnya karya seni merupakan daya tarik awal bagi penonton untuk menyaksikan sebuah karya seni.

Judul yang unik merupakan nilai tambah bagi sebuah karya sehingga penonton bisa di buat penasaran ingin menyaksikan sebuah karya. Judul yang penata pilih untuk koreografi ini adalah "Kaawakan Ulun", kata ini berasal dari kata dasar Awak dan Ulun yang diambil dari bahasa suku Banjar, salah satu suku yang ada di Propinsi Kalimantan Selatan dan salah satu suku pendatang yang ada di Kalimantan Timur. Judul ini terdiri dari dua kata dasar, yaitu awak yang berarti badan atau tubuh dan ulun yang memiliki arti aku atau saya, kata ini diberi awalan ke yang apabila di katakan oleh orang Banjar menjadi $k a(\mathrm{H}$. Oemar Daclan. 2000. Kalimantan Timur Dengan Aneka Ragam Permasalahan Dan Berbagai Peristiwa Bersejarah Yang Mewarnainya. Jakarta; Yayasan Bina Ruhui Rahayu Jakarta. p. 206), dan akhiran an, sehingga menjadi kata kaawakan ulun, yang dapat diartikan ketubuhan aku atau ketubuhan saya.

Pemilihan bahasa Banjar untuk digunakan sebagai judul pada koreografi ini dikarenakan penata terlahir dan besar di dalam 
keluarga yang memiliki suku Banjar, sehingga kata-kata ini tidak asing bagi penata. Bahasa Banjar juga menjadi bahasa yang umum di Kalimantan Timur terutama di Samarinda sebagai Ibu Kota dari propinsi Kalimantan Timur. Suku pendatang seperti suku Bugis, Jawa dan Cina, yang tinggal di Samarinda kebanyakan dapat berbahasa Banjar dengan baik, bahkan suku Dayak dan Kutai sekalipun juga dapat berbahasa Banjar dengan lancar. Hal-hal inilah yang mendorong penata memilih bahasa Banjar untuk dijadikan judul pada koreografi ini.

\section{Bentuk Dan Cara Ungkap}

Penyajian koreografi Kaawakan Ulun ini dalam bentuk tari kelompok dengan tipe dramatik dan studi. Tidak ada dialog dalam koreografi ini, para penari hanya membangun suasana dan alur cerita yang dibuat penata. Gerak-gerak dan motif-motif tari tradisional Dayak dan Melayu Kutai menjadi gerak serta motif dasar yang digunakan dan dikembangkan untuk koreografi kelompok ini

\section{E. Gerak Tari}

Elemen dasar dari sebuah koreografi adalah gerak. Adapun pemilihan gerak pada karya koreografi ini merupakan hasil eksplorasi dan improvisasi yang dilakukan penata sendiri maupun bersama penari. Gerak yang terdapat pada koreografi Kaawakan Ulun ini, merupakan gerak-gerak atau motif-motif tari tradisional yang terinspirasi dari tari tradisional yang ada di Kalimantan Timur seperti gerak ngancet, kepak enggang, motif samba, ayun anak, tahtim dan ndayung. Gerak serta motif yang telah didapat untuk koreografi Kaawakan Ulun ini dilakukan secara rampak simultan dan rampak kontras, juga mengembangkan beberapa gerak dan motif dengan menggunakan arah hadap, level dan waktu. Gerak-gerak tersebut juga dilakukan secara mengalun, dalam koreografi ini penata juga menggunakan gerak saling mengisi, muka belakang dan canon

\section{F. Adegan}

Penyajian koreografi Kaawakan Ulun ini dalam bentuk tari kelompok dengan tipe dramatik dan studi. Tidak ada dialog dalam koreografi ini, para penari hanya membangun suasana dan alur cerita yang dibuat penata. Gerak-gerak dan motif-motif tari tradisional Dayak dan Melayu Kutai menjadi gerak serta motif dasar yang digunakan dan dikembangkan untuk koreografi kelompok ini. Adapun beberapa adegan yang dibuat dalam koreografi ini adalah :

\section{Introduksi}

Koreografi ini diawali dengan menampilkan dua pasang penari yang masingmasing menggunakan kostum tari tradisional Dayak dan Melayu Kutai, mereka menari sesuai dengan kostum yang mereka kenakan. Di bagian ini penata ingin menampilkan suasana Kalimantan Timur dan sekaligus memperkenalkan kepada penonton bahwa Kalimantan Timur memiliki dua budaya yaitu budaya Dayak dan Melayu Kutai. Kemudian juga dihadirkan lima orang penari, diantaranya dua orang penari wanita dan tiga orang penari pria. Jumlah ini dipilih karena terinspirasi pada pengalaman penata yang pernah memiliki sebuah grup tari dengan jumlah lima orang. Gerak-gerak tari di luar dari gerak tradisional penata tampilkan di bagian ini sesuai dengan pengalaman dan kemampuan penata sebelum belajar di Institut Seni Indonesia Yogyakarta. Tiga orang penari pria yang menari menggunakan properti bendera Marching Band pada bagian ini juga dihadirkan sebagai gambaran kegiatan penata sebagai pelatih Colour Guard dan sempat menjadi penari Colour Guard di ISI Yogyakarta. Bendera yang digunakan penari Colour Guard memiliki unsur yang dapat mewakili unsur budaya yang terdapat pada koreografi ini, seperti pada budaya Dayak bendera yang digunakan terdapat gambar yang menyerupai ukiran Dayak, sedangkan untuk budaya Melayu Kutai akan menggunakan kain yang bermotif kotak-kotak atau sering di sebut motif belang Hatta yang menjadi motif khas pada 
sarung Samrinda (http://sarungtenunsamarinda.blogspot.co.id/2013/05/galeri-

roses-pembuatan sarungtenun. html. Aldhi Murazqi. Galeri Proses Pembuatan Sarung Tenun Samarinda. 2013. Diunduh pada tanggal 20 September 2015).

\section{Adegan 2}

Gerak-gerak yang ditampilkan pada bagian ini merupakan gerak-gerak yang terinspirasi dari gerak tari tradisional Dayak, seperti gerak kepak enggang yang terdapat pada tari Datun, gerak ngancet, nguhuk atau teriakan khas Dayak Kalimantan Timur. Musik yang terdapat pada bagian ini juga musik dengan sentuhan Dayak. Suara sape, gong, kekanong akan mewarnai iringan pada bagian ini.

\section{Adegan 3}

Gerak-gerak yang ditampilkan pada bagian ini merupakan gerak-gerak yang terinspirasi dari gerak tari Jepen Kutai, seperti gerak ndayung, tahtim, gelombang, samba dan ayun anak. Musik yang terdapat pada bagian ini juga musik dengan sentuhan Melayu Kutai. Suara gambus atau panting, ketipung serta nyanyian yang sering disebut betingkilan (Zailani Idris. Kutai Obyek Perkembangan Tradisional Di Kalimantan Timur. Jakarta. 1997. p. 93) mewarnai iringan pada bagian ini.

\section{Adegan 4}

Bagian ini merupakan penggabungan dua unsur budaya Dayak dan Melayu Kutai, menggambarkan budaya ini tumbuh harmonis dan damai di Kalimantan Timur. Terdapat lima orang penari pada bagian ini dua orang menggunakan kostum tari tardisional Dayak dan dua orang menggunakan kostum tari tradisional Jepen Kutai serta satu orang yang menggambarkan kedua budaya tersebut menyatu dalam dirinya.

\section{Adegan 5 / Ending}

Properti berupa lima helai kain dengan warna yang berbeda beda yaitu merah, hitam, putih, kuning dan hijau hadir pada bagian akhir ini. Kain tersebut turun dari atas bagian tengah panggung dan kain ini digunakan seperti pada tari Anyam Tali Kalimantan Timur. Properti ini dihadirkan sebagai lambang menyatunya kedua budaya tersebut seperti pada makna yang terdapat pada Tari Anyam yang memiliki makna persatuan dalam perbedaan. Empat orang penari yang berdiri di atas sebuah sebuah level yang berbentuk setengah lingkaran hadir di bagian tengah belakang panggung. Satu penari wanita yang menggunakan kostum tari Dayak berdiri di level paling atas, kemudian satu penari wanita yang menggunakan kostum tari Jepen Kutai berada di level tengah sedangkan penari pria yang mengenakan kostum tari Dayak berdiri di sebelah kanan di level bawah dan penari pria yang mengenakan kostum tari Melayu Kutai berdiri di sebelah kiri di level bawah.

\section{Penari}

Jumlah penari pada koreografi ini adalah tujuh belas orang penari, dengan jumlah penari wanita tujuh orang dan sepuluh orang penari pria, jumlah penari ini telah dibagi sesuai bagian atau tugas masingmasing. Terdapat sepuluh orang sebagai penari inti pada koreografi ini diantaranya lima penari wanita dan lima penari pria. Koreografi ini menggunakan tujuh penari pendukung dengan jumlah penari wanita dua orang dan penari pria lima orang. Penari inti pria dan wanita dipilih dengan jumlah yang sama karena penata terinspirasi pada pengalaman penata yang pernah memiliki grup tari dengan jumlah penari lima orang. Melihat pada koreografi ini terdapat bagian yang terinspirasi pada tari jepen Kutai yang biasa ditarikan berpasangan, maka dipilihlah jumlah sepuluh untuk penentuan jumlah penari inti. Dua penari pendukung pria dan dua penari pendukung wanita dipilih untuk menghadirkan dua budaya Dayak dan Melayu Kutai, masingmasing budaya tersebut dihadirkan secara berpasangan untuk menyimbolkan kesuburan dan kekayaan alam Kalimantan Timur. Jumlah tiga orang 
penari Color Guard dipilih karena masing masing menggunakan properti dengan simbolsimbol yang telah penata paparkan di atas, yaitu Dayak, Melayu Kutai dan penggabungan dua budaya tersebut, maka didapatlah jumlah tujuh belas orang penari untuk koreografi ini. Jumlah tujuh belas ini juga dilihat dan dipertimbangkan dari kebutuhan yang ada dalam karya ini, seperti transisi dari pergantian kostum yang mempermudah tehknis pada saat pentas di atas panggung.

\section{Tata Rias dan Busana}

Rias dan busana pada koreografi Kaawakan Ulun ini menggunakan rias cantik atau rias korektif untuk para penari wanita, dan rias natural panggung untuk penari pria. Sementara untuk busana yang digunakan pada koreografi ini adalah kostum yang dapat mewakili ketiga nuansa seperti yang dijelaskan di atas, yaitu kekinian, Dayak dan Melayu Kutai. Penata merancang sebuah kostum yang nantinya bisa menjadi satu kesatuan dari ketiga unsur tersebut.

Kostum yang digunakan pada koreografi ini adalah kostum tari tradisional Dayak dan Melayu Kutai, serta menggunakan kostum yang telah mengalami eksplorasi dan proses kreatif oleh piñata namun tetap ada unsur tradisional Dayak dan Melayu Kutai seperti tumpukan payet yang membentuk ukiran Dayak dan penggunaan kain bermotif kotak-kotak. Warna hitam dipilih untuk digunakan pada kostum tari tradisional Dayak, sedangkan untuk kostum tradisional Melayu Kutai, dipilih warna merah marun. Warna kostum yang dieksplorasi oleh penata, lebih kepada warna kuning dan hijau, serta juga menggunakan kain bermotif kotak-kotak yang warnanya disesuai dengan kedua warna di atas. Warna dan motif pada bahan kostum ini memiliki makna tersendiri di Kalimantan Timur dan juga sering dijumpai dibeberapa kostum serta pernak pernik manik-manik khas Dayak yang ada di Kalimantan Timur.

Kostum yang digunakan untuk penari yang menggunakan properti bendera adalah kostum yang berwarna hitam dengan kombinasi warna silver dan abu-abu warna ini dipilih untuk mangimbangin lima penari introduksi lain agar tidak terkesan berbeda dan seimbang, pada kostum ini tidak ada sentuhan tradisi.

Terdapat beberapa kostum yang digunakan dalam koreografi ini. Kostum yang digunakan juga disesuaikan dengan dua unsur kebudayaan tersebut, sehingga pada koreografi ini akan dilakukan pergantian kostum. Kostum tari tradisional dari suku Dayak yang digunakan penari pria terdiri dari, cawat dan juga bluqo sebagai penutup kepala. Penari pria ini menggunakan properti yang ia pegang di tangannya yaitu sebuah tameng atau perisai dan sebuah senjata tajam khas suku Dayak yaitu Mandau. Sedangkan penari Melayu suku Kutai, menggunakan baju kurung lengan panjang berkerah tinggi menutupi leher, celana panjang, sarung khas Samarinda dengan motif belang Hatta (motif kotak-kotak) sepanjang lutut dan memakai peci bermotif belang Hatta senada dengan sarung yang digunakan dan diselipkan bulu berwarna jingga diatas sebelah kiri peci tersebut. Kostum tari tradisional dari suku Dayak yang digunakan penari wanita terdiri dari baju tanpa lengan yang diberi hiasan berupa ornamen ukiran Dayak yang disusun menggunakan manik-manik dan payet. Bagian bawah untuk kostum ini menggunakan ta'ah (rok) payet atau manic sepanjang mata kaki dan juga menggunakan bluqo berhiaskan bulu burung enggang sebagai penutup kepala. Penari wanita ini menggunakan properti yang ia pegang di kedua tangannya, yaitu bulu burung enggang yang dirangkai. Sedangkan yang menggunakan kostum tari melayu suku Kutai menggunakan baju kurung lengan panjang berkerah tinggi menutupi leher, pada bagian bawah lengannya dibuat sedikit melebar dengan kombinasi kain bermotif belang Hatta, menggunakan rok panjang menutupi mata kaki. Rok yang digunakan adalah sarung Samarinda dengan motif khas belang Hatta, baju yang digunakan juga dikombinasi dengan kain sarung Samarinda dengan motif belang Hatta yang sama. Bagian kepalanya menggunakan sanggul berbentuk 
kerucut dibagian bawah sanggul diberi bunga melati yang dipasang mengelilingi lingkaran bagian bawah sanggul, serta menggunakan satu kembang goyang (mentul) yang diselipkan pada bagian atas sanggulnya.

Tiga orang penari inti pria pada bagian introduksi menggunakaan jaket lengan panjang berwarna hitam dikombinasi sedemikian rupa dengan bahan yang berwarna abu-abu dan silver. Celana yang digunakan adalah celana panjang berwarna hitam yang dikombinasikan dengan warna abu-abu dan Silver senada dengan jaket yang dikenakan, peletakan kombinasi warna abu-abu dan silver masingmasing dibuat berbeda.

Kostum yang digunakan penari inti pria pada bagian tari Dayak adalah rompi berwarna hijau yang terdapat payet berwarna gold bermotif ukiran Dayak di bagian dada sebelah kiri dan belakang, serta menggunakan ikat kepala berwarna kuning dan mereka menggunakan celana panjang berwarna kuning dan penutup bagian depan celana yang menyerupai ukiran khas Dayak. Dibagian bawah celana terdapat motif ukiran khas suku Dayak. Penari pria menggunakan tato berwarna hitam dibagian lengan dari atas hingga lengan bagian bawah kiri dan kanan. Saat masuk dibagian tari Melayu Kutai mereka menggunakan baju lengan panjang berwarna kuning, dengan bagian ujung lengannya terdapat kain bermotif kotak-kotak, dengan bentuk kerah tinggi semacam bentuk teluk belanga bermotif kotak-kotak. Penari pria menggunakan kain bermotif kotak-kotak dibagian pinggang sampai kelutut, dan juga menggunakan peci bermotif kotak-kotak senada dengan sarung atau kain yang mereka kenakan dengan dihiasi bros pada bagian depan dan sisi kiri serta diberi hiasan dua helai bulu berwarna jingga. Dibagian akhir penari pria menggunakan baju yang digunakan pada saat tari Melayu Kutai, namun pada celananya diberi penutup bagian depan yang digunakan pada kostum untuk bagian tari Dayak. Peci yang digunakan ditambah satu helai bulu burung enggang disamping sebelah kiri. Lidwina Lirung yang melihat penutup celana bagian depan yang dikenakan penari inti pria mengatakan bentuk ukiran yang dibuat kurang melingkar pada bagian ujung ukiran sehingga terlihat kurang maskulin dan disarankan untuk membenahi agar terlihat lebih maskulin dan dapat mewakili karakter laki-laki suku Dayak serta tidak menghilangkan khas Kalimantan Timur dari bentuk ukiran pada penutup celana bagian depan (Wawancara dengan Lidwina Lirung, seniman tari Kalimantan Timur, berusia 37 tahun, pada tanggal 15 November 2015, di kediaman Fauji Romansyah J1 Jogoripon Yogyakarta (diijinkan untuk dikutip).).

Dua penari inti wanita pada bagian introduksi ini menggunakan jaket warna hitam yang dikombinasikan dengan warna abu-abu dan silver. Penari wanita menggunakan rok berwarna abu-abu yang dikombinasikan dengan warna silver dan hitam senada dengan jaket yang digunakan, peletakan kombinasi warna abu-abu dan silver masing-masing dibuat berbeda. Penari Dayak wanita menggunakan baju tanpa lengan berwarna kuning, dengan belahan samping panjang hingga kepaha, bagian dada terdapat payet berwarna hijau yang bermotif ukiran khas Dayak. Dibagian bawah baju terdapat pemberat berupa manik-manik berukuran sedang dan koin berwarna emas serta tambahan bulu-bulu berwarna hitam. Panjang baju penari wanita dibawah lutut. Penari wanita menggunakan gelang berwarna putih, masing-masing tangan menggunakan dua gelang, selain itu di bagian lengan atas masing masing menggunakan gelang manik dengan hiasan berupa gigi taring hewan. Untuk bagian kepala, rambut penari wanita disasak dan disanggul sederhana, dan diberi hiasan pita berhiaskan permata tiruan di sekeliling lingkaran bagian bawah sanggul tersebut dan di beri hiasan manik-manik berwarna emas. Terdapat tiga helai bulu burung enggang yang ditaruh di sanggul penari wanita dan seraung berwarna hijau diletakan diatas sebelah kanan kepala serta menggunakan gelang lengan atau klat bahu terbuat dari manikmanik berhiaskan taring hewan tiruan dan gelang berwarna 
putih.Paha para penari wanita terdapat tato berwarna hitam bermotif ukiran khas Dayak. Bagian tari Melayu Kutai penari wanita menggunakan rok panjang hingga mata kaki bermotif kotak-kotak senada dengan yang terdapat pada kostum penari inti pria dikombinasikan dengan warna kuning serta ditambah kain songket berwarna hijau pada bagian luar rok, dan menggunakan rompi lengan panjang berwarna hijau polos dengan bagian ujung lengan bermotif kotak-kotak dan dibuat sedikit melebar. Bagian kepala penari wanita terdapat seraung kecil berwarna hijau yang dipasang di kepala bagian samping depan sebelah kanan, tidak menggunakan bulu burung enggang lagi.

Bagian akhir koreografi ini penari wanita menggunakan rok panjang hingga mata kaki bermotif kotak-kotak dikombinasikan dengan warna kuning dibagian depan terdapat ornamen berwarna merah dan hijau. Rompi yang digunakan pada tari Melayu Kutai dan kain songket dilepas tersisa baju berwarna kuning tanpa lengan bermotif ukiran dayak di bagian dada sama seperti baju pada bagian tari Dayak. Bagian kepala masih sama seperti yang terdapat pada bagian tari Dayak dan gelang lengan atau klat bahu terbuat dari manikmanik berhiaskan taring hewan tiruan dan gelang berwarna putih kembali dipakai.

\section{Properti dan Seting}

Bagian terakhir atau ending pada koreografi Kaawakan Ulun ini menggunakan tumpukan trap atau level yang disusun sedimikian rupa dan di atas tumpukan trap atau level tersebut terdapat sebuah level lagi yang menyerupai bentuk gong namun dibuat setengah lingkaran. Trap atau level setengah lingkaran ini dibuat lebih besar dari ukuran gong pada umumnya agar dapat terlihat dengan jelas dari jarak penonton. Bagian sisi trap atau level setengah lingkaran ini terdapat ornamen berupa ukiran khas Dayak.

Lima helai kain yang menjuntai hingga ke lantai panggung dengan warna yang berbeda-beda yaitu merah, biru, putih, kuning dan hijau juga hadir pada koreografi ini, kain tersebut turun dari atas bagian tengah panggung. Kain ini digunakan penari sebagai properti tari seperti yang terdapat pada tari Anyam Tali Kalimantan Timur.

Lidwina Lirung menyarankan warna hitam sebagai salah satu warna khas di Kalimantan Timur diganti dengan warna biru tua atau jingga, agar dapat terlihat dengan jelas keindahan dalam permaianan kain tersebut karena ruang pertunjukan yang digunakan dikelilingi dengan warna hitam (Wawancara dengan Lidwina Lirung, seniman tari Kalimantan Timur, berusia 37 tahun, pada tanggal 12 Maret 2016, di rumah makan siap saji Mcdonald Jl Sudirman Yogyakarta (diijinkan untuk dikutip).). Menurut piñata warna biru tua lebih mendekati dengan warna hitam dan menurut penata warna jingga mirip dan mendekati dengan warna kuning. Video pertunjukan tari Anyam Tali atau tari Persatuan yang piñata lihat dari Youtube terdapat sepuluh kain yang digunkan untuk menari dan salah satu warna kain tersebut adalah warna biru tua (https://www.youtube.com/watch?v=7GHsQi0 ZwQ4. Jalan Poros. Pampang Dayak Kenyah Part 1. 23 Maret 2016. Diunduh pada tanggal 5 April 2016.) maka dari itu penata memilih warna biru tua untuk mengganti warna hitam pada seting dan properti dalam karya ini.

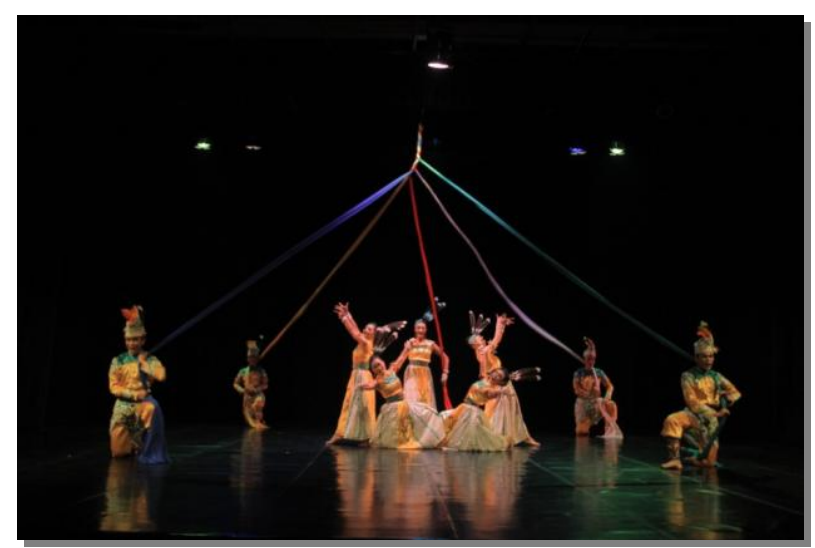

Gambar 7 : Adegan ending dengan seting dan properti berupa lima helai kain yang turun dari parapara, digunakan untuk menari dan membentuk sebuah anyaman tali (foto: Uncle Joe, 2016) 


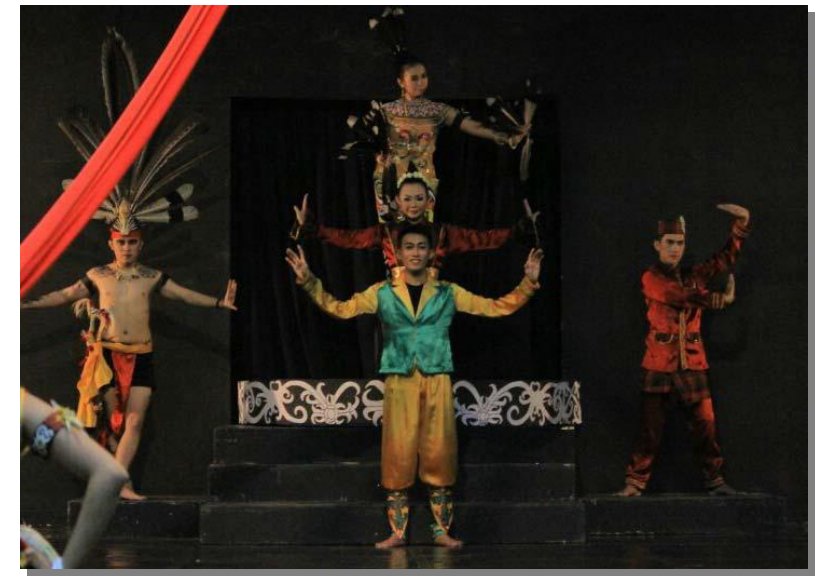

Gambar 8. Seting panggung pada adegan ending berupa tumpukan trap atau level. Trap paling atas berbentuk setengah lingkaran dengan hiasan ornamen ukiran Dayak. (foto : Uncle Joe)

Properti tongkat yang diberi bendera seperti yang digunakan para penari Colour Guard pada marching band juga digunakan untuk koreografi ini. Properti ini penata gunakan untuk menyimbolkan kebudayaan yang penata pegang dalam kehidupannya. Bendera yang digunakan terdapat corak yang mewakili unsur kebudayaan yang penata angkat pada koreografi ini. Properti ini penata gunakan karena penata terinspirasi pada kegiatan penata beberapa tahun lalu yang menjadi pelatih Colour Guard dan juga pada saat penata mengikuti kegiatan Marching Band di Institut Seni Indonesia Yogyakarta. Koreografi ini di dalamnya juga terdapat properti bulu-bulu burung Enggang yang dirangkai dan diselipkan di kedua tangan penari wanita yang menggunakan kostum tari tradisional Dayak dan Tameng serta Mandau yang dipegang penari pria yang menggunakan kostum tari tradisional Dayak.

I

\section{Musik Tari}

Musik yang digunakan pada koreografi Kaawakan Ulun ini adalah musik digital yang dibuat melalui program dan aplikasi komputer dan musik yang telah direkam sebelumnya.

Musik pengiring Kaawakan Ulun ini, menggabungkan beberapa unsure musik, diantaranya musik yang berunsur tradisional yang ada di Kalimantan Timur, yaitu musik dengan unsur Dayak dan Melayu Kutai. Musik ini diberi sentuhan kekinian, baik dari segi tempo dan penambahan instrumen yang menghasilkan suara yang berbeda dengan musik Dayak dan Jepen Kutai pada umumnya.

Musik iringan yang dibuat melalui program dan aplikasi komputer ini, dimasukan suara dari alat musik sape, bas, gambus, dan suara-suara yang membangun suasana. Sentuhan music Datun, Kancet Pepatay yang lebih berfokus pada suara sape, serta irama Tingkilan juga dihadirkan pada koreografi ini. Suara-suara dari alat musik tersebut sengaja dipilih agar dapat mewujudkan suasana musik yang penata inginkan, yaitu Dayak dan Melayu Kutai.

Setiap bagian pada koreografi ini memiliki nuansa musik yang berbeda sesuai dengan konsep yang penata buat. Tidak hanya iringan yang bersumber dari alat musik saja yang digunakan dalam koreografi ini namun pada koreografi ini juga terdapat iringan yang bersumber dari vocal. Seperti yang penata buat pada adegan introduksi, pada bagian ini terdapat senandung-senandung dengan irama khas Dayak yang membuat suasana tradisional Kalimantan Timur lebih terasa.

\section{Tata Cahaya}

Tata cahaya sangat penting peranannya dalam seni pertunjukan, yang harus mampu menciptakan suatu nuansa luar biasa, serta mampu menarik perhatian penonton terhadap Tontonannya (Hendro Martono. 2010. Mengenal Tata Cahaya Seni Pertunjukan. Yogyakarta. Multi

Grafindo. p. 11.).

Permainan komposisi pola lantai penari pada koreografi ini menjadi perhatian penata, seting panggung dan properti tari sangat membutuhkan dukungan penyinaran yang baik, selain untuk menyampaikan kesan dan pesan dari setiap elemen tersebut, juga mengajak penonton untuk berimajinasi.

Sebuah gedung proscenium stage dengan fasilitas yang cukup memadai untuk sebuah pertunjukan garapan tari yang berkelas 
ujian menjadi tempat untuk menampilkan karya koreografi Kaawakan Ulun. Maka dari itu penata menggunakan tata cahaya dengan fasilitas yang terdapat di gedung tersebut. Dengan pola focus one point, two point dan three point, penata menggunakan cahayacahaya yang dapat membangun suasana, seperti suasana sejuk dan suasana-suasana yang dapat mewakili karya Kaawakan Ulun ini.

Cahaya yang digunakan tentunya dapat mendukung karya koreografi ini, seperti membangun suasana perasaan para penari yang ingin disampaikan kepaada para penonton, atau bisa juga menjadi transisi perpindahan adegan. Cahaya tersebut juga dapat menonjolkan beberapa bagian, seperti make up dan kostum yang digunakan para penari seperti lampu yang terpasang di daerah side wing lampu-lampu ini dapat membantu menonjolkan eberapa bagian dri tubuh para penari seperti bagian betis, badan dan juga wajah. Lampu LED yang dapat memancarkan beberapa warna cahaya dapat membantu membangun suasana pada koreografi ini.

\section{KESIMPULAN}

Karya "Kaawakan Ulun" ini terinspirasi dari pengalaman pribadi penata yang merasa tidak memiliki kemampuan untuk menari tarian tradisional, terutama tarian tradisional yang berasal dari daerah sendiri yaitu Kalimantan Timur. Melalui pendidikan tari yang sedang dijalani sekarang ini, sedikit banyak penata mulai mengenal tari tradisional. Hal ini membuat penata merasa malu karena tidak tahu budaya daerah asal, maka penata mulai mencari serta belajar tarian tradisional Kalimantan Timur.

Pengalaman yang sangat berharga dari proses karya koreografi Kaaawakan ulun menjadi suatu pengalaman berkesan dalam hidup. Kesabaran menghadapi orang banyak dan ketabahan menerima beberapa penghambat proses merupakan pengalaman berkesan dalam membentuk kepribadian yang lebih baik. Semua pendukung dalam karya koregrafi ini baik yang berperan di balik karya maupun beberapa orang yang ditemui sangat membantu dan memberikan tambahan ilmu bagi penata.

Sebagai koreografer penata merasa masih kurang berhasil dalam menggarap karya koreografi ini, karena sebagai orang yang berkuasa penuh dalam karya ini penata masih terlalu takut untuk bertindak tegas, terutama dalam proses latihan. Proses yang dijalani dalam membuat karya ini penata rasa masih kurang lancar, karena latihan yang dilakukan juga masih bersamaan dengan perkuliahan, sehingga para penari juga sering telat datang dengan alasan baru selesai kuliah dan beristirahat sebentar, selain itu padatnya latihan yang dilakukan para penari juga menjadi alas an penari untuk datang terlambat atau bahakan ijin pulang duluan sebelum latihan selesai.

\section{DAFTAR RUJUKAN}

\section{A. Sumber Tercetak}

Amin, Mohd. 1997. Pedoman Lagu dan Seni Tari Rakyat Kalimantan Timur. Kalimantan Timur: Departemen pendidikan dan Kebudayaan Kalimantan Timur.

Dachlan, H. Oemar. 2000. Kalimantan Timur Dengan Aneka Ragam Permasalahan Dan Berbagai Peristiwa Bersejarah Yang Mewarnai. Jakarta: Yayasan Bina Ruhui Rahayu Jakarta.

Hadi, Y. Sumandiyo. 2012. Koreografi Bentuk-Teknik_isi. Yogyakarta: Cipta Media.

2003 Aspek-Aspek Dasar Koreografi Kelompok. Yogyakarta : Elkaphi. 
Idris, Zailani. 1977. Kutai Obyek Perkembangan Kesenian Tradisional Di Kalimantan Timur. Jakarta.

Luna, Hikari dan Amira Iffat. 2015. Mahir Menjahit Tingkat Dasar Sampai Terampil. Klaten: Hafamira.

Martono, Hendro. 2008. Sekelumit Ruang Pentas. Yogyakarta: Cipta Media. 2012.

Ruang Pertunjukan dan Berkesenian. Yogyakarta: Multi Grafindo. . 2010.

Mengenal Tata Cahaya Seni Pertunjukan. Yogyakarta: Cipta Media.

Maulana, Achmat. 1985. Ungkapan Tradisional Sebagai Sumber Informasi Kebudayaan Daerah Kalimantan Timur. Jakarta: Departeman Pendidikan Dan Kebudayaan Proyek Inventarisasi Dan Dokumentasi Kebudayaan Daerah.

Meri, La. 1975. Dance Composition: The Basic Elements. Terjemahan Soedarson, Komposisi Tari ElemenElemen Dasar. Yogyakarta: Lagaligo.

Murhansyah. 2006. Erau Kemilau Kearifan Masa Silam, Pondok Gede: Ganeca Exact.

Muzakir, Djahar. 2010. Cerita Rakyat Kalimantan Timur 20 Cerita Rakyat Kaltim Terbaik, Jakarta : Pustaka Spirit.

Naim, Ngainum. 2012. Character Building. Yogyakarta: Ar-Ruzz Media.

Nugroho, Eko. 2008. Pengenalan Teori Warna. Yogyakarta: Andi.

Nugroho, Sarwo. 2015. Manajemen Warna dan Desain. Yogyakarta: Andi.
Obeng, Djumri. 1980. Tingkilan dan Tarsulan Suku Kutai, Jakarta: Proyek Penerbit Buku Sastra Indonesia dan Daerah.

Pamungkas, Adi Jarot. 2008. Dasar dan Aplikasi Musik Digital, Yogyakarta: Andi.

Ramlan, H. 2012. Ilmu Bahasa Indonesia, Yogyakarta : Cv Karyono.

Risyahibban, TT. Album Ragam Hias Suku Modang, Kalimantan Timur: Proyek Bimbingan Dan Pengembangan Industri Kecil (BIPIK) Kanwil Dept. Perindustrian Prop Kalimanatan Timur.

Sari, Puspa Sekar. 2014. Rahasia Cepat Membuat dan Mendesain Baj Sendiri. Jakarta: Dunia Kreasi.

Smith, Jacqueline. 1975. Komposisi Tari: Sebuah Pertunjukan Praktik Bagi Guru, terjemahan Ben Suharto. Yogyakarta: Ikalasri Yogyakarta.

Susanto, Eko. 2005. Gelora Kaltim, Samarinda : Biro Humas Pemerintahan Propinsi Kalimantan Timur.

Thowok, Didik Nini. 2012. Stage Make-up By Didik Ninik Towok Untuk Teater Tari dan Film. Jakarta: PT Centro Inti Media.

\section{A. Sumber Tidak Tercetak}

Lidwina Lirung , 37 tahun, aktif dalam kegiatan seni, khususnya seni Kalimantan Timur. Bertempat tinggal di Jl Lubang Buaya, Jakarta.

\section{B. Webtografi}

http://www.kutaikartanegarakab.go.id/index.p hp/static/lambang_kabu paten/. Pemerintah Kabupaten Kutai Kartanegara. Lambang Kabupaten . 2013. Diunduh pada tanggal 16 September 2015. 
http://www.kidnesia.com/Kidnesia2014/Indon esiaku/Jalan-Jalan/Rahasia-Warna-ManikManik-Dayak. Lita. Rahasia Warna ManikManik Dayak. Agustus 2015. Diunduh pada tanggal 16 September 2015.

http://www.kompasiana.com/tien.kusumawati/ proses-penciptaansebuah-karyatari_55003c6da333117c6f510551.

Tien Kusumawati. Proses Penciptaan Sebuah Karya Tari. Diuanggah ke internet pada tanggal 30 Oktober 2010. Diunduh pada tanggal 12 September 2015.

http://sarungtenun-

samarinda.blogspot.co.id/2013/05/galeri-

proses pembuatan sarung-tenun.html. Aldhi Murazqi. Galeri Proses Pembuatan Sarung Tenun Samarinda. 2013. Diunduh pada tanggal 20 September 2015. 
